\title{
RUBY-THROATED HUMMINGBIRD ASSOCIATING WITH A FORAGING HAIRY WOODPECKER
}

SPENCER G. SEALY, Department of Zoology, University of Manitoba, Winnipeg, Manitoba. R3T 2N2

On 20 May 1983 a female Hairy Woodpecker was observed foraging on the trunk of a Green Ash on the forested dune ridge, about $5 \mathrm{~km}$ west of Delta, Manitoba. A male Ruby-throated Hummingbird flew to within a few $\mathrm{cm}$ of the woodpecker then withdrew until it was about $2 \mathrm{~m}$ away and hovered. It repeated this sequence three more times over the next minute or so. The woodpecker then moved abruptly toward the hummingbird, by sidling on a branch. The hummingbird flew to and perched on a branch in the same tree, about $3 \mathrm{~m}$ form the woodpecker. A few seconds later, the woodpecker chased the hummingbird out of my sight. I did not see the woodpecker or hummingbird again at the woodpecker's original foraging site.

Numerous workers have reported hummingbirds feeding on sap from holes drilled by Yellow-bellied Sapsuckers at northern latitudes, ${ }^{179}$ and in the tropics at holes drilled by Acorn Woodpeckers. ${ }^{2}$ Evidence is mounting that hummingbirds actually associate with sapsuckers, ${ }^{5}$ and that Ruby-throated Hummingbirds may follow them as they forage, thus facilitating locating drilled holes where sap may be obtained. ${ }^{3}$

The association between the Rubythroated Hummingbird and Hairy Woodpecker that I described raises some interesting questions. Was this association merely coincidental? Ruby-throated Hummingbirds occur in the dune-ridge forest during spring migration (Sealy, unpubl. data), and I have observed such individuals foraging on leaf buds, including those of Green Ash, possibly ingesting exudate or insects that have become entangled in it. The hummingbird and woodpecker may have just come together in the same tree, and the described interactions ensued. ${ }^{4}$ On the other hand, the hummingbird may have associated the woodpecker's foraging mode with a possible source of food, regardless of whether the woodpecker was a sapsucker, or it possibly mistook the foraging Hairy Woodpecker for a sapsucker, a bird about the same size, and investigated it. Hummingbirds are known to investigate various colors, including red, 6810 and they might be expected occasionally to cue into the red patch on the back of the head of male Hairy Woodpeckers. However, female Hairy Woodpeckers lack the patch of red feathers.

\section{Acknowledgments}

This observation was made while I conducted studies of passerine reproductive biology on the forested dune ridge, Delta Marsh, Manitoba. Keith $\mathrm{A}$. Hobson read an early draft of the manuscript and pointed out a couple of pertinent references. This work was funded by grants from the Natural Sciences and Engineering Research Council of Canada. This contribution is number 123 of the University of Manitoba Field Station (Delta Marsh).

'FOSTER, W.L. and J. TATE, IR. 1966. The activities and coactions of animals at sapsucker trees. Living Bird 5:87-113.

2KATTAN, G. and C. MURCIA. 1985. Hum- 
mingbird association with Acorn Woodpecker sap trees in Colombia. Condor $87: 542-543$.

KKNAPTON, R.W., R.V. CARTER and J.D. REYNOLDS. 1985. Do hummingbirds follow sapsuckers to food sources? Blue lay $43: 186-187$

MARLER, P. 1956. Studies of fighting in Chaffinches (3) Proximity as a cause of aggression. Br. I. Anim. Behav. 4:23-30.

MILLER, R.S. and R.W. NERO. 1983. Hummingbird-sapsucker associations in northern climates. Can. I. Zool. 61:1540-1546.

${ }^{6 M I L L E R, ~ R . S ., ~ S . ~ T A M M, ~ G . D . ~ S U T H E R L A N D ~}$ and G.L. GASS. 1985. Cues for orientation in hummingbird foraging: color and position. Can. I. Zool. 63:18-21.
7SOUTHWICK, E.E. and A.K. SOUTHWICK 1980. Energetics of feeding on tree sap by Ruby-throated Hummingbirds in Michigan. Amer. Midl. Nat. 104:328-334.

"STILES, F.G. 1976. Taste preferences, color preferences, and flower choice in humminghirds. Condor 78:10-26.

'SUTIHERLAND, G.D., G.L. GASS, P.A. THOMPSON and K.P. LERTZMAN. 1982. Feeding teritoriality in migrant Rufous Hummingbirds: defense of Yellow-bellied Sapsucker (Sphyrapicus larius) feeding sites. Can. I. Zool. 60:2046-2050.

10WELKER, H.J. 1984. Food color preference in the Anna's Humminghird. West. Birds 15:23-27.

Fred W. Lahrman

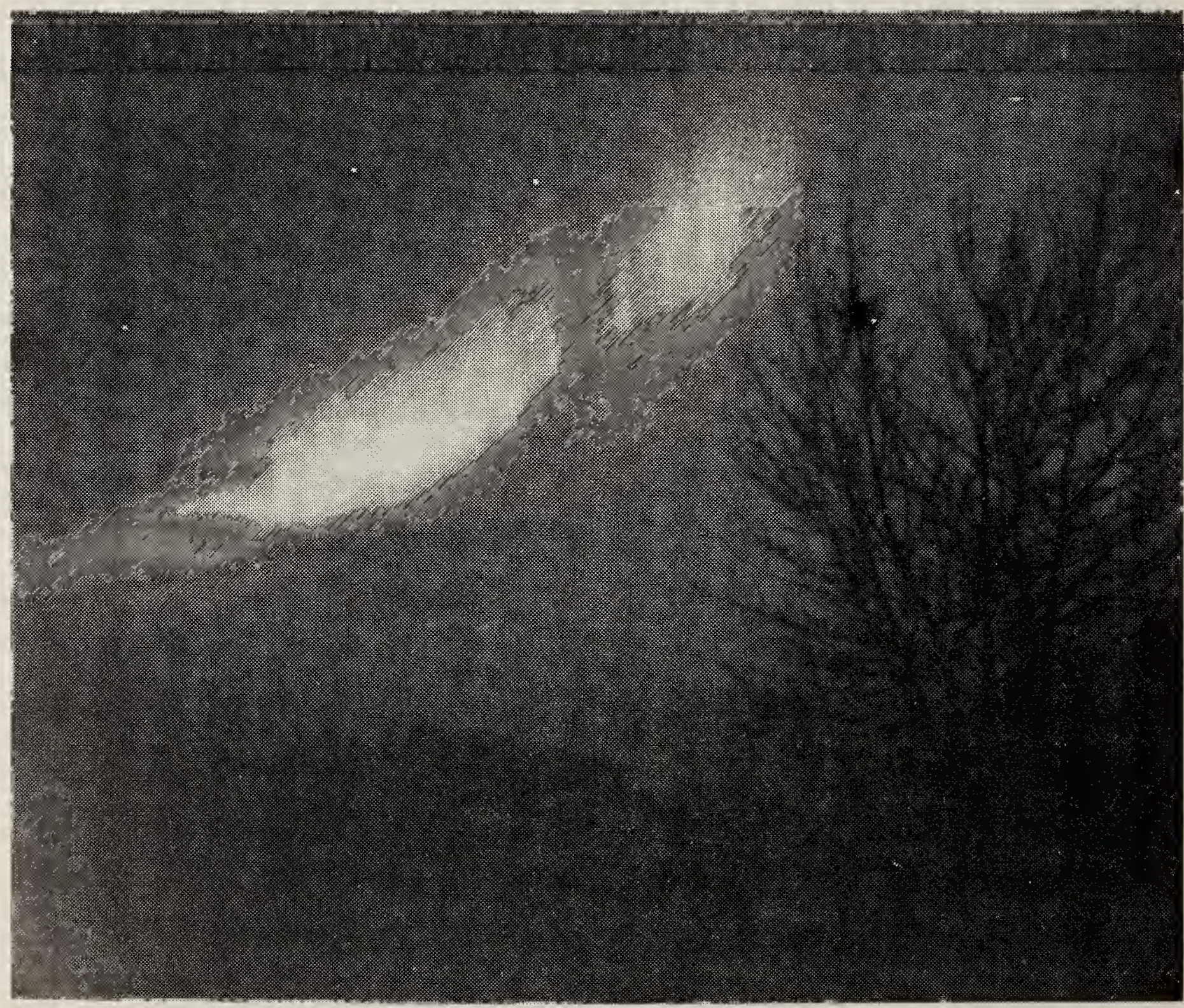

